\title{
The Influence of Green Marketing on Perceived Value of Pertamax Purchasing Decision
}

\author{
Rennyta Yusiana \\ Telkom University \\ Bandung, Indonesia \\ rennyta@tass.telkomuniversity.ac.id
}

\author{
Arry Widodo \\ Telkom University \\ Bandung, Indonesia \\ arrywie@telkomuniversity.ac.id
}

\begin{abstract}
Environmental degradation intensifies in Indonesia and in the world giving direct impact on human life. The issue of care for the environment and as a form of social responsibility, prompting many companies to create and offer environmentally friendly products (green product). This study aims to determine the effect of Green marketing on perceived value in the consumer purchase decisions on fuel pertamax in Bandung. This type of research is descriptive and causal research by using path analysis. Methods of data collection using a questionnaire with a sample of 400 respondents. The sampling technique used in this study is simple random sampling. The analysis showed Green marketing influence on purchasing decisions directly is lower than Green marketing influence through perceived value to the purchasing decision. This matter that the perceived value of the variable is very important in creating a purchasing decision pertamax. Future studies are expected to examine the dominant factors in variable thus increasing the perceived value of a purchase decision.
\end{abstract}

Keywords: green marketing, green product, perceived value, the purchase decision.

\section{INTRODUCTION}

Earth environmental damage has occurred many centuries ago, starting with the world wars and their human nature which is always creating new things, but to make the surrounding environment damage (Luthfiana, 2013). United Nations as a representative body of the nations also took part in the implementation, including the holding of the Environment Conference in Stockholm, Sweden, on June 15, 1972. This conference was a forum to address various problems and issues concerning the environment.

Globalization makes people easily obtain information about the world's environmental issues such as global warming. Depletion of natural resources due to global warming made people start to worry and realize that a lot of the products that they use to be one of the contributors to environmental damage (De Moura et al., 2012). Such as coral reef degradation, water and air pollution, global warming, waste management issues that is quite understandable by the public. A preventive way is one thing that must be done prior to the occurrence of damage as mentioned (Hult, 2011).

Smart companies view environmental issues as an opportunity to satisfy the needs and desires of consumers. The company will apply the environmental issues in marketing activities that they do, giving rise to a new phenomenon in the world of marketing of the concept of green marketing. The company sees the product as a green business opportunities and apply it as a long-term business strategy (Hult, 2011; Pujari \& Wright, 1996; Johri \& Sahasakmontri, 1998). Moreover, sustainable consumption has drawn more attention from corporate decision makers due to stricter environmental regulation and growing stakeholder pressures focused on preserving the environment (Hult, 2011).

Many companies use ads promoting the planting of trees as a form of Corporate Social Responsibility (CSR). It was promoted to the environment around the location of the company. In this way the company took part in various activities or events that involved anticipating campaign about global warming today. To promote Green Products, marketers must focus on consumer preferences and decision-making processes (Cherrier et al., 2011). The use of basic materials that are environmentally friendly products to a trademark will make prospective consumers to decide whether to make a purchase on the trademark or not. Society expects good impact on the environment for the foreseeable future for the continuation of the descendants of today's society.

Green marketing is currently a major topic of society in anticipating the defects of nature. Not just cosmetic or restaurants that are environmentally friendly products, but the fuel could say such things. Fuel oil is a product that is sensitive in the community because it is one important aspect of social life. The use of vehicles that each increase the level of pollution in the surrounding environment and even lead to global warming. Meta-analysis reveals that environmental concern is one of the important sustainability variables in green marketing literature (Wiernik et al., 2013).

Green marketing strategy requires a lot of cost to test whether the product to be issued by the company has been qualified as an environmentally friendly product. In addition, the company that labels itself as a company that took part in Green marketing strategies also have to pay to participate in the events of social and environmental greening program or local City (Singh and Gupta, 2013). This is particularly important for large companies with many branches to perform these activities in the city of the local branch. Nevertheless, to prevent further environmental degradation more research is needed to understand consumers' Green Product purchase behavior in de- veloping countries that have varied 
environmental concern, belief, and attitudes than their counterparts across world (Singh and Gupta, 2013).

The campaigns and promotions by the company is expected to raise public awareness on the issues raised, particularly awareness on customers. By doing campaign is also expected to increase public awareness of the products concerned with the environment around it. When they buy the product, then they have participated in the campaign by the company. The Company conducted a campaign to sensitize the public to the issues raised (Cherrier et al., 2011; Kusumawati, 2009). However, the biggest challenge faced by the company are changes in consumer preferences, suspicion towards the recognition of green advertising, consumer perception is not favorable for green product and high costs in developing green product. Therefore, knowing the attitude of consumers towards green product or environmentally friendly products has been very important (Chai and Chen; 2010).

The attitude of consumers who receive green product is when their main needs of the function or performance of the product, the quality, convenience and affordability are met (Singh and Gupta, 2013; Chai and Chen; 2010; Ottman, 1992).

In this study raised the importance of green products issued by Pertamina as the operator of a fuel provider in Indonesia with environmentally friendly products such as Pertamax Ron 92 (research octane number). Therefore, Pertamina is already aware of the importance of environmentally friendly products, but it raises other considerations such as price are the main factors that must be considered in consumer behavior in purchasing (Bukhari, Syeda Shazia, 2011). In addition to the emergence of environmentally friendly products (Polonsky, 1994), driven by high levels of pollution in the region in this case Indonesia, especially the city of Bandung, where the current growth rate of vehicles is increasing rapidly. With air pollution levels that occur during this time such as forest fires, pollution from factories and the largest is the rate of motor vehicle pollution, resulting in air quality that occurs when this becomes less good.

\section{GREEN MARKETING}

Green marketing is a strategic efforts undertaken by the company to provide goods and services that are environmentally friendly to the consumer target (Brammer et al., 2012; Grewal and Levy, 2010). According to (D'Souza et al., 2015; Kumar, 2014; Ko et al., 2013; Leonidou et al., 2013; Hawkins et al., 2007: 93) There are several indicators as follows: (1) Green marketing involves the process of developing a product: production, use and disposal of the wastes are harmful to the environment than other types of traditional products; (2) Green marketing involves the process of developing products that have a positive impact on the environment; (3) Green marketing should also be tying the sale of products with organizations and activities related to environmental care.

As conventional marketers, Green marketing requires innovative marketing tool. In the aim of offering target consumers with quality products at a time when and the right place, for the right price it would require a four-part marketing tools are: product, price, promotion and place (Singh, 2010). 1.) Green Product. Green product is defined as a product that will not pollute the earth or deplete natural resources and can be recycled or conserved (Shamdasami et al, 1993). Green products are items that one character is using good materials, which can be recycled and the process of making green product also uses waste management is good, so that, overall use of green products means reducing carbon emissions, and helped reduce the impact of global warming (Nature, 2011).

2.) Green Price. Most green product requires extra costs by consumers as a product of higher quality and environmentally friendly. The things to consider in the green price according to Singh (2010: 4), is as follows: a.) Higher price for products; b.) Does the price cover the real cost of production, or do customers feel exploited?

3.) Green Promotion. Promotion or communication about green product issued by a company must be in accordance with what is produced. Things that should be considered in the promotion of green (Singh, 2010: 5), are as follows: a.) Keep jobless honest, truthful, decent and not misleading; b.) In media selection choose 'green' media. (Radio and TV create no waste, some magazines are printed on recycled paper)

4.) Green Place. Option where and when to make the product available, have a significant impact on the customer to be interested. According to Shabani et al. (2013: 1882) argues that green distribution channel has the following characteristics: packaging products for transport to distribution sites must minimize waste and use of raw materials. Transport the products to the distribution should be directed to reducing environmental damage, such as reducing energy consumption and reduce pollution.

The perceived value is the overall assessment of the utility of products based on the perception that is given and received perception. Acceptable values consumers are saving the environment will determine consumers to buy products that implement Green marketing strategy in product creation process. Based on (D'Souza et al., 2015; Kumar, 2014; Pujari 2003) research, green marketing has a positive impact on the company, among others: increased sales, improve customer feedback, closer to the customer, enhance competitiveness, increasing the company's image.

Good impact for the company in addition to getting the sales increase, consumers also will shortly join the company's streotipe promoting environmental protection, In addition to the company's image will improve with this stigmatizing (Leonidou et al., 2013). Even certain products are gaining increasing both image and get a place in the hearts of consumers or users (Kumar, 2014; Leonidou et al., 2013).

Purchase decision is the decision to buy the most preferred brand is influenced by two factors: the attitude of other people and situational factors that are not expected (Brammer et al., 2012; Hult, 2011; Kotler and Armstrong, 2008). According to Kurtz and Boone (2006), purchase decisions is the phase of search and evaluation of alternatives 
of the decision process, which resulted in a final buying decision and action to buy.

There are five stages that assessed consumers in the purchase decision process that is problem recognition, information search, evaluation of alternatives, purchase decision, and post purhcase behavior, but consumers do not always go through the five stages of the purchase of the product as a whole, they may be passing or flipping several stages in decision-making process (Kotler and Keller, 2012).

The proposed hypothesis of this research to determine whether Green marketing significantly influence purchasing decisions and Green marketing influence purchasing decisions through perceived value.

\section{RESEARCH METHODOLOGY}

This reserach investigates whether Green marketing significantly influence purchasing decisions and Green marketing influence purchasing decisions through perceived value. The independent variable of this research is green marketing $(\mathrm{X})$ consist of green product, green price, and green promotion. The intervening variable is the perceived value $(\mathrm{Y})$ consist of Appropriateness, Prices Inappropriate, Offering Good Value and Compliance with Product Prices. Meanwhile the dependent variable is purchase desicion ( $\mathrm{Z}$ ) consist of Product Options, Options Brand, Channel selection, purchase amount, time of purchase and payment method.

Based on the aim and the variables stated above, this research is categorized as a descriptive and quantitative, uses SPSS and Path. This research test the hypothesis of Green marketing influence purchasing decisions through perceived value.

\section{FINDING \& DISCUSSIONS}

The results of path analysis illustrated in Figure 1 below.

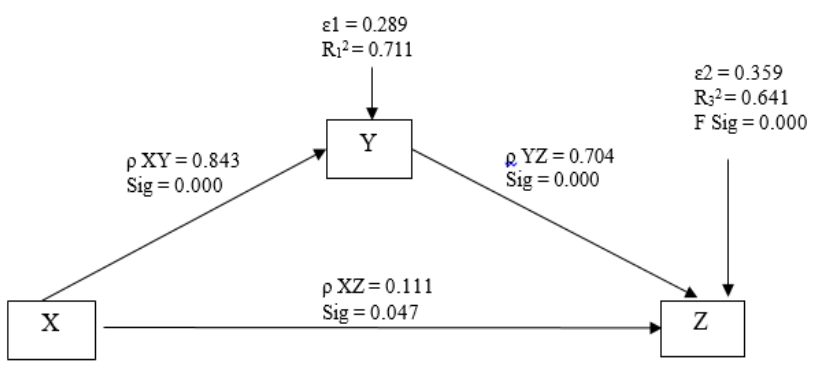

Figure 1. Path Analysis

Note :

$\mathrm{X}$ : Green Marketing

Y : Perceived Value

$\mathrm{Z}$ : Purchasing decision

Based on calculations using SPSS and path, there is a relationship between green marketing and perceived value of
0.843 , or has the effect of $71 \%$ and green marketing together with the perceived value influence the purchase decisions of $64 \%$.

Path analysis shows the relationship of green marketing directly to the purchasing decision is at 0.111 or has the effect of $1.23 \%$.

This research shows that perceived value can influence purchase decisions on products pertamax. It can be seen from the calculation that the influence of green marketing and perceived value together on purchasing decisions have a higher impact than the direct influence of green marketing to purchasing decision.

\section{CONCLUSION \& SUGgeSTIONS}

Based on the results of research and discussion, along with the theories that support the influence of Green Marketing on Perceived Value and Purchase Decision products fuel oil (BBM) type pertamax in Bandung then obtained the following conclusions:

1. Green marketing influence on Perceived Value in Pertamax consumer in Bandung by $71 \%$.

2. Perceived Values influence on consumer buying decision on Pertamax in Bandung amounted to $49.56 \%$.

3. Green marketing direct influence on consumer buying decision on Pertamax in Bandung amounted to $1.23 \%$.

4. Green marketing together with the perceived value influence the purchase decisions on consumers Pertamax in Bandung by $64 \%$.

\section{REFERENCES}

[1] Boztepe, Aysel. (2012). Green marketing and Its Impact on Consumer Buying Behavior.5(1),7 European Journal of Economic and Political Studie.

[2] Bukhari, Syeda Shazia. (2011). Green marketing and its impact on consumer behavior Journal of Business and Management. 3(4), 375.

[3] Cherian Jacob, Jacob Jolly. (2012). Green marketing: A Study of Consumers' Attitude towards Environment Friendly Products. Canadian Center of Science and Education.

[4] Cherrier, H., Black, I.R., Lee, M., 2011. Intentional non-consumption for sustain- ability: consumer resistance and/or anti-consumption. Eur. J. Mark. 45 (11/12), 1757-1767.

[5] D’Souza, C., Taghian, M., Sullivan-Mort, G. And Gilmore, A. (2015), "An evaluation of the role of green marketing and a firm's internal practices for environmental sustainability", Journal of Strategic Marketing, 23 (forthcoming), doi:10.1080/0965254X.2014.1001866, available www.tandfonline.com/doi/abs/10.1080/0965254X.2014.1001866\#.VX Lh-8-qqko

[6] Dahlstorm, Robert. (2010). Green marketing Management. United States of America: South - Western Cengage Learning.

[7] Dean, M., Raats, M.M., Shepherd, R., 2012. The role of self-identity, past behaviour and their interaction in predicting intention to purchase fresh and processed organic food. J. Appl. Soc. Psychol. 42 (3), 669688 .

[8] Dewi, Anisa Indriani. (2011). Pengaruh Green marketing Terhadap Persepsi Konsumen Produk The Body Shop Cabang Bandung Indah Plaza. Perpustakaan Fakultas Komunikasi dan Bisnis Bandung. 
[9] Frendy, Jerdinan S. (2013). The Impact Of Perceived Value Customer Statisfaction And Repurchase Intention Of Blackberry Users In Manado.jurnal EMBA vol.1 No.4 Desember 2013, Hal 1650-1658.

[10] Ghozali, Nanang. 2012. Metode Penelitian Kuantitatif. Cetakan ke-1. Bandung. Pustaka setia, cv.

[11] Hult, G.T.M., 2011. Market-focused sustainability: market orientation plus!. J. Acad. Mark. Sci. 39, 1-6. Hutchins.

[12] Istijanto. (2009). Aplikasi Praktis Riset Pemasaran. Jakarta. Gramedia.

[13] Kampani Poppy, Kumadji Srikandi, Kusumawati Andriani. (2014). Pengaruh Green marketing Terhadap Nilai Yang Dipersepsikan Dalam Keputusan Pembelian Mobil (Studi pada Konsumen PT Astra International Tbk.-TSO Malang Sutoyo. Universitas Brawijaya Malang

[14] Kemala Diany. (2013). Pengaruh Green marketing Terhadap Consumer Behaviour Dan Pembentukan Brand Image Pada The Body Shop. Perpustakaan Fakultas Komunikasi dan Bisnis Bandung.

[15] Ko, E., Hwang, Y.K. and Kim, E.Y. (2013), "Green marketing' functions in building corporate image in the retail setting", Journal of Business Research, Vol. 66 No. 10, pp. 1709-1715.

[16] Kotler, Philip \& Armstrong, Gary. (2008). Prinsip-prinsip Pemasaran (Edisi 12 Jilid 1). Jakarta. Erlangga.

[17] Kotler, Philip \& Armstrong, Gary. (2008). Prinsip-prinsip Pemasaran (Edisi 12 Jilid 2). Jakarta. Erlangga.

[18] Kotler, Philip \& Keller, Kevin Lane. (2009). Manajemen Pemasaran (Edisi 13 Jilid 1). Jakarta. Erlangga.

[19] Kotler, Philip., \& Keller. (2012). Marketing Management (14th Edition). New Jersey, USA: Pearson Prentice Hall.

[20] Kotler, Philip \& Gary Armstrong (2010). Principles of Marketing, 13th edition, United states of America: Pearson

[21] Kumar, P. (2014), "Greening retail: an Indian experience", International Journal of Retail and Distribution Management, Vol. 42 No. 7, pp. 613-625.

[22] Leonidou, C.N., Katsikeas, C.S. andMorgan, N.A. (2013), “'Greening' themarketing mix: do firms do it and does it pay off?", Journal of Academy of Marketing Science, Vol. 41 No. 2, pp. 151-170.

[23] Mahendra, Methodius T. (2016). Analisis Green Marketing pada PT.Tama Cokelat Indonesia (Studi Kasus Gerai Chocolatiqe Paris Van Java Bandung).Universitas Telkom

[24] Malhotra, Naresh K. (2009). Riset Pemasaran (Marketing Research) (Edisi 4 Jilid 1). New Jersey, Indonesia: PT. Indeks.

[25] Marhadi, Ayu Nursyamsi, Noviasari Henni. (2013). Pengaruh Strategi Green marketing Pada Bauran Pemasaran Terhadap Keputusan Konsumen Dalam Membeli Rumah Di Perumahan PT. Asta Karya Pekanbaru. Universitas Riau

[26] Manongko, Allen A. Ch (2011). Green marketing Dan Pengaruhnya Terhadap Keputusan Pembelian Melalui Minat Membeli Produk Organik (Studi Pada Pelanggan Produk Organik di Kota Manado). www.scholar.google.com

[27] M Rahmansyah. (2013). Pengaruh Green marketing Dalam Iklan Produk Terhadap Keputusan Konsumen. Universitas Hasanuddin Makassar

[28] Putripeni, Mayang Pradma \& dkk. (2014). Pengaruh Green marketing Terhadap Citra Merek Dan Keputusan Pembelian, 10(1). Jurnal Administrasi Bisnis.www.scholar.google.com
[29] Oztek Yaman, Cengel Ozgur. (2013). The Formation of Green Buying Strategy on the Scope of Consumer Decision Making Behavior. AJITe: Online Academic Journal of Information Technology

[30] Polonsky Jay Michael. (1994). Introduction To Green marketing. Electronic Green Journal, University of Newcastle

[31] Riduwan. (2010). Metode dan Teknik Menyusun Tesis. Bandung. Alfabeta.

[32] Riduwan, Kuncoro. (2012). Metode \& Teknik Menyusun Proposal Penelitian. Bandung: Mandar Maju

[33] Romadon, yusuf. (2014). Pengaruh Green Marketing Terhadap Brand Image dan Struktur Keputusan Pembelian(Survey pada Followers Account Twitter @ PertamaxIND pengguna Bahan Bakar Ramah Lingkungan Pertamax Series). Jurnal Administrasi Bisnis vol.15 No.1 Oktober 2014

[34] Sarkar, Anirban. (2012). Green Marketing And Sustainable Development-Challenges And Opportunities. International Journal of Marketing, Financial Services \& Management Research.

[35] Shiffman, Leon \& Kanuk, Leslie Lazar. (2008). Perilaku Konsumen (Edisi 7). Jakarta. Indeks

[36] Singh, N., Gupta, K., 2013. Environmental attitude and ecological behaviour of In- dian consumers. Soc. Responsib. J. 9 (1), 4-18.

[37] Siregar,Syofian. (2013). Metode Penelitian Kuantitatif Dilengkapi Dengan Perbandingan Perhitungan Manual \& SPSS. Jakarta: Kencana.

[38] Syahbandi. (2013). Implementasi Green marketing Melalui Pendekatan Marketing Mix, Demografi Dan Pengetahuan Terhadap Pilihan Konsumen (Studi The Body Shop Pontianak. Jurnal Ekonomi, Bisnis Dan Kewirausahaan

[39] Sugiyono. (2013). Statistika untuk Penelitian. Bandung. Alfabeta

[40] Sunjoyo, Setiawan Rony, dkk. (2013). Aplikasi SPSS untuk SMART Riset. Bandung. Alfabeta.

[41] Saworno Jonathan. (2012). Path Analysis dengan SPSS: Teori, Aplikasi, Prosedur Analisis untuk Riset Skripsi, Tesis dan Disertasi. Jakarta. PT.Elex Media Komputindo.

[42] Tan Booi Chen \& Lau Teck Chai (2010); Attitude towards the Environment and Green Products: Consumers' Perspective, Management Science and Engineering, pp. 27-39.

[43] Wiernik, B.M., Ones, D.S., Dilchert, S., 2013. Age and environmental sustainability: a meta-analysis. J. Manag. Psychol. 28 (7/8), 826-856.

[44] Yazdanifard, Rashad \& Mercy, Igbazuo Erdoo. (2011). The impact of Green marketing on Customer satisfaction and Envi- ronmental safety. Vol.5, 637. IACSIT Press, Singapore.

[45] Yu-Shan Chen Ching-Hsun Chang. (2012). Enchance Green Purchase Intentions; The Roles Of Green Perceived Value, Green Perceived Risk, and Green Trust. Department of Business Adminsitration, National Taipei University. Taiwan 